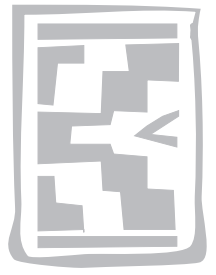

\title{
Characterization of pigeon paramyxoviruses (Newcastle disease virus) isolated in South Africa from 2001 to 2006
}

\author{
C. ABOLNIK ${ }^{1 *}$, G.H. GERDES ${ }^{1}$, J. KITCHING ${ }^{2}$, S. SWANEPOEL ${ }^{3}$, M. ROMITO1 \\ and S.P.R. BISSCHOP4
}

\begin{abstract}
C. ABOLNIK, G.H. GERDES, J. KITCHING, S. SWANEPOEL, M. ROMITO \& S.P.R. BISSCHOP. 2008. Characterization of pigeon paramyxoviruses (Newcastle disease virus) isolated in South Africa from 2001 to 2006. Onderstepoort Journal of Veterinary Research, 75:147-152

Pigeon paramyxovirus type 1 (PPMV-1), a variant of Newcastle disease virus that primarily affects doves and pigeons has been isolated in South Africa since the mid-1980s. Phylogenetic evidence indicates that pigeon paramyxovirus type 1 viruses were introduced into South Africa on multiple occasions, based on the presence of two separate lineages, 4bi and $4 \mathrm{bii}$, that have been circulating in Europe and the Far East since the early 1990s. During 2006, a PPMV-1 virus was isolated from an African ground hornbill (Bucorvus leadbeateri) which became acutely infected with PPMV-1 and died, probably after scavenging off infected dove carcasses in the region, since a closely-related PPMV-1 strain was also isolated from doves collected nearby. The hornbill isolate had ICPI and MDT values characteristic of PPMV-1 strains. The threat of PPMV-1 to poultry production and biodiversity in southern Africa highlights the importance of monitoring the spread of this strain.
\end{abstract}

Keywords: African ground hornbill, Newcastle disease virus, paramyxovirus, phylogenetic characterization, pigeon

\section{INTRODUCTION}

Pigeon paramyxovirus type 1 (PPMV-1) is an antigenic variant of avian paramyxovirus type 1 (APMV-1; Newcastle disease virus) that was first identified by monoclonal antibody binding studies (Alexander, Wilson, Thain \& Lister 1984; Alexander, Russell,

* Author to whom correspondence is to be directed. Email: abolnikc@arc.agric.za

1 ARC-Onderstepoort Veterinary Institute, Private Bag X5, Onderstepoort, 0110, South Africa

2 Stellenbosch Provincial Veterinary Laboratory, Private Bag X1, Elsenburg, 7607, South Africa

3 Deltammune Laboratories, P.O. Box 14167, Lyttleton, Centurion, 0140, South Africa

4 Poultry Reference Laboratory, University of Pretoria, Private Bag X04, Onderstepoort, 0110 South Africa

Accepted for publication 14 April 2008-Editor
Parsons, Abu Elzein, Ballouh, Cernik, Engstrom, Fevereiro, Fleury, Guittet, Kaleta, Kinm, Kosters, Lomniczi, Meister, Meulemans, Nerome, Petek, Pokomunski, Polten, Prip, Richter, Sághy, Samberg, Spanoghe \& Tumova 1985; King 1996; Lana, Snyder, Kink \& Marquart 1988). PPMV-1 strains caused outbreaks among racing and show pigeons in Europe in 1981 and re-emerged in 1985 causing a panzootic that continues today (Biancifiori \& Fioroni 1983; Alexander et al. 1985; Wilson 1986; Kaleta 1992a, b; Ujvári, Wehman, Kaleta, Werner, Savić, Nagy, Czifra \& Lomniczi 2003; Aldous, Fuller, Mynn \& Alexander 2004). In pigeons and doves clinical signs of infection include neurological signs such as torticollis and paralysis, and the excretion of large volumes of green, watery diarrhea (Alexander et al. 1984; 1985; Lemahieu, De Vriese \& Bijnens 1985). In chickens, intracerebral pathogenicity (ICPI) values for PPMV-1 are typical of mesogenic Newcastle 
disease viruse but in most cases, PPMV-1 isolates have increased their virulence for chickens after passage, and therefore represent a threat to poultry production (Alexander \& Parsons 1986; King 1996; Kommers, King, Seal \& Brown 2001). Besides pigeons, doves and chickens, PPMV-1 viruses have also been isolated from kestrels, falcons, cockatoos, budgerigars, pheasants, swans and a robin (Alexander et al. 1985; Lister, Alexander \& Hogg 1986; Kaleta 1992b; Werner, Römer-Oberdörfer, Köllner, Manvell \& Alexander 1999; Monne, Beato, Capua \& Mandola 2006; Aldous et al. 2004). Phylogenetic analysis has classified PPMV-1 strains into a discrete lineage, Vlb (Lomniczi, Wehman, Herczeg, Ballagi-Pordany, Kaleta, Werner, Meulemans, Jorgensen, Manté, Gielkens, Capua \& Damoser 1998), recently re-classified as lineage $4 b$. Lineage $4 b$ was further split into subgroups 4bi and 4bii (Aldous et al. 2004).

Large die-offs in doves and pigeons have occasionally been reported in various parts of South Africa since the 1980s after the first isolation of PPMV-1 from doves during an outbreak in September 1986 (Pienaar \& Cilliers 1987). In the present study, the phylogenetic relationships between 21 South African PPMV-1 viruses isolated from doves, pigeons, chickens, a duck and an African ground hornbill (Bucorvus leadbeateri) were investigated, and the pathogenicity of the African ground hornbill isolate for chickens was determined.

\section{MATERIALS AND METHODS}

\section{Isolates}

Virus isolation was performed at the Onderstepoort Veterinary Institute, Stellenbosch Provincial Veterinary Laboratory, the University of Pretoria's Poultry Reference Laboratory and Deltammune Laboratory by inoculation into the alantoic cavities of 9 to 10-day-old embryonated specific antibody-negative fowl eggs. Isolates are indicated in Table 1.

TABLE 1 South African pigeon paramyxovirus isolates

\begin{tabular}{|c|c|c|c|c|}
\hline Isolate & Year & Host & Town, Province ${ }^{a}$ & Accession number \\
\hline ZA469/PPMV1/02 & 2002 & 28-week-old layers & Mooirivier, KZN & AY445669 \\
\hline PIZA04N230 & 2004 & Racing pigeons & Oudtshoorn, WC & EF030962 \\
\hline DOZA05N240 & 2005 & Doves & Kimberly, NC & EF030953 \\
\hline DOZA05N247 & 2005 & Laughing dove & Kuilsrivier, WC & EF030954 \\
\hline PIZA05N277 & 2005 & Pigeon & Pretoria, GP & EF030963 \\
\hline DOZA05AM68313 & 2005 & Laughing dove & Marikana, NWP & EF030952 \\
\hline DOZA05N417 & 2005 & Doves & Montagu, WC & EF030955 \\
\hline DOZA05N539 & 2005 & Doves & Belville, WC & EF030956 \\
\hline DOZA06N549 & 2006 & Doves & Cape Town, WC & EF030957 \\
\hline DOZA06N589 & 2006 & Doves & Darling, WC & EF030958 \\
\hline DOZA06N591 & 2006 & Doves & Kimberly, NC & EF030959 \\
\hline CKZA06N606 & 2006 & 4-week-old broilers & Sibasa, LP & EF030951 \\
\hline DOZA06UP470 & 2006 & Dove & Polokwane, LP & EF030961 \\
\hline PIZA06N642 & 2006 & Pigeon & Cape Town, WC & EF030950 \\
\hline DOZA06N621 & 2006 & Doves & Cape Town, WC & EF030960 \\
\hline -ZA06N690 & 2006 & Unknown & Germiston, GP & \\
\hline PIZA06N699 & 2006 & Pigeon & Middleburg, MPU & \\
\hline PIZA06N635 & 2006 & Pigeon & Stellenbosch, WC & EF030964 \\
\hline DOZA06N757 & 2006 & Laughing doves & Dwaalboom, NWP & \\
\hline BLZA06N779 & 2006 & African ground hornbill & Dwaalboom, NWP & \\
\hline DKZA06N828 & 2006 & Muscovy duck & Worchester,WC & \\
\hline
\end{tabular}

a KZN KwaZulu-Natal

WC Western Cape

NC Northern Cape

LMP Limpopo

NWP North West

GP Gauteng

MPU Mpumahlanga 


\section{Pathogenicity tests}

ICPI and MDT tests were performed according to standard procedures (OIE manual of standards: diagnostic tests and vaccines 2000).

\section{Reverse transcription-polymerase chain reaction and nucleotide sequencing}

Viral RNA was extracted from alantoic fluid using TRIzol ${ }^{\circledR}$ reagent (Gibco, Invitrogen). The fusion (F) protein gene was targeted in a one-step RT-PCR using the oligonucleotide primer pair and thermal cycling parameters described elsewhere (Abolnik, Horner, Maharaj \& Viljoen 2004). Cycle sequencing was performed using the ABI PRISM ${ }^{\circledR}$ Big Dye ${ }^{\mathrm{TM}}$ Terminator Cycle Sequencing Ready Reaction Kit (Applied Biosystems) and the reverse primer from the RT-PCR to span the region containing the $F_{0}$ peptide cleavage site. Reactions were analysed with an $\mathrm{ABI} 3130^{\mathrm{TM}}$ Genetic Analyser (Applied Biosystems).

\section{Sequence analysis}

Nucleotide and amino acid sequence analyses and alignment were carried out using Bioedit (Hall 1999) and ClustalW software

(http://www.ebi.ac.uk/clustalw/index.html).

Phylogenies were reconstructed with MEGA 3.1 software (Kumar, Tamura \& Nei 2004) using the neighbour-joining tree inference method with the Kimura 2-parameter substitution model and 1000 bootstrap replicates to assign confidence levels to branches.

\section{RESULTS AND DISCUSSION}

Phylogenetic analysis of partial $F$ protein genes indicated that the South African PPMV-1 isolates do not cluster together as a single geographical entity, but instead are split between the two lineages $4 \mathrm{bi}$ and 4bii (Fig. 1). One of the South Africa isolates, PIZA05N277, isolated from a pigeon in Pretoria (Gauteng Province) in May 2005 shared $99 \%$ nucleotide sequence identity with the other international lineage 4bi viruses, but only $98-99 \%$ and $94-95 \%$ sequence identities with other South African lineage 4bi and lineages 4bii viruses, respectively. Therefore, we suspect that this strain was recently introduced into the country. The muscovy duck (Cairina moschata) (DKZA06N828) was a suspected organophosphate poisoning case and probably contracted PPMV-1 through contact with faeces from infected doves. CKZA06N606 was isolated from 4-week-old broilers and is only the second reported case of
PPMV-1 infection of chickens in South Africa. The African ground hornbill isolate, BLZA06N779 shared $99.4 \%$ sequence identities in the partial fusion protein gene with DOZA06N757 isolated from doves on the same farm during the outbreak. An MDT value of $89.4 \mathrm{~h}$ was obtained for BLZA06N779, which falls within the $90 \mathrm{~h}$ time limit for mesogenic viruses. The ICPI value obtained was 0.33 , which indicates that it is not velogenic but does not differentiate between mesogenic and lentogenic viruses.

The South African lineage 4bii strains formed a single clade and these viruses were mainly obtained from the Western Cape Province, apart from single isolates from Gauteng (-ZA06N690) and KwaZuluNatal Provinces (ZA469/PPMV1/02). Nucleotide sequence homology within the South African clade varied from $96.7 \%$ to $99.1 \%$. Relatively longer branch lengths suggest that the lineage 4 bii strains may have been circulating in South Africa for an extended period. The sequences of ${ }^{112} R R Q K R F^{117}$ and ${ }^{112} \mathrm{RRKKRF}{ }^{117}$ at $\mathrm{F}_{0}$ for lineages $4 \mathrm{bi}$ and $4 \mathrm{bii}$, respectively (Fig. 2), are in agreement with other reports (Collins, Strong \& Alexander 1994; Mase, Imai, Sanada, Sanada, Yuasa, Imada, Tsukamoto \& Yamaguchi 2002; Meulemans, Van den Berg, Decaesstecker \& Boschmanns 2002; Terregino, Cattoli, Grossele, Bertoli, Tisato \& Capua 2003).

Although the bootstrap values supporting the phylogenetic relationships within lineages 4bi and 4bii are low, amino acid sequences (Fig. 2) support the phylogenetic relationships: lineage 4 bi clade (c) is distinguished from clades (a) and (b) (Fig. 1) by $\mathrm{T}^{3}$, $L^{10}$ and $R^{27}$ substitutions, and lineage 4 bii clade $(d)$ differs from clade (e) by a $\mathrm{P}^{36} \rightarrow \mathrm{S}$ substitution.

We have demonstrated that exotic strains of pigeon paramyxoviruses were introduced into South Africa on multiple occasions. Routes of introduction into South Africa are speculative, although they are most likely via the importation of infected pigeons for racing and ornamental purposes as reported in other countries (Aldous et al. 2004). A second case of PPMV-1 infection of chickens in South Africa is reported here, highlighting the importance of the threat of PPMV-1 to poultry, but PPMV-1 also potentially threatens biodiversity of wild birds, particularly rare indigenous dove and pigeon species. We report the first isolation of PPMV-1 from an African ground hornbill (Bucorvus leadbeateri), an increasingly rare species, which became acutely infected with PPMV-1 and died, although the virus did not display increased pathogenicity for chickens. It is likely that the ground hornbill became infected by scavenging off the dead doves in the area. Our findings suggest that PPMV-1 
Pigeon paramyxoviruses (Newcastle disease virus) isolated in South Africa

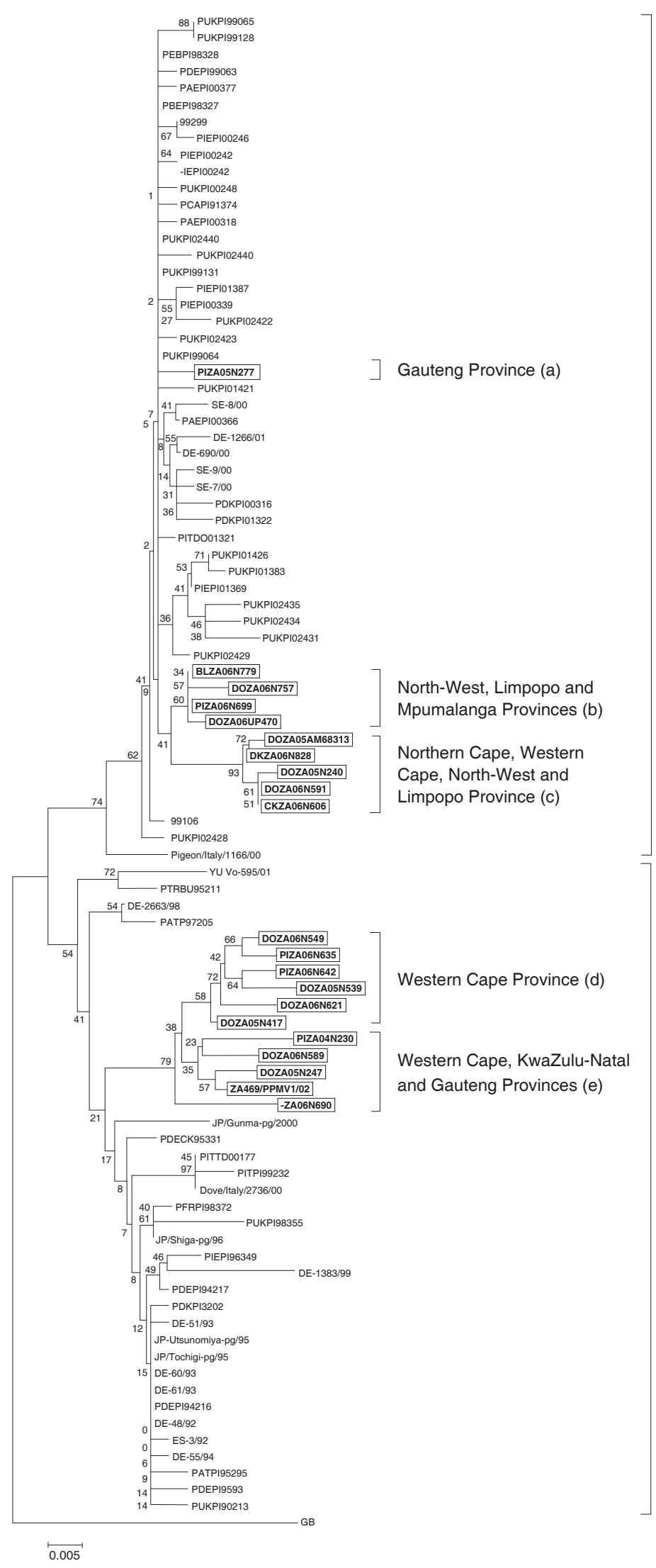

Lineage 4bi

Europe, United Arab Emirates and South Africa
Lineage $4 \mathrm{bii}$

Europe, South Africa and Japan

FIG.1 Phylogenetic tree of a 374-bp region of the fusion protein gene of PPMV-1 viruses. South African strains are framed (bold type) 





infection may be lethal to species other than doves and pigeons. Identification of molecular virulence determinants of paramyxoviruses other than the $F_{0}$ cleavage site, and identification of host-specific factors that affect virulence are research areas that require more attention.

\section{ACKNOWLEDGEMENTS}

We thank Elsa Cornelius, Piekie Combrink, Hope Kekana and Magdeline Dreyer for performing virus isolations, and Emily Lane for submitting the African ground hornbill samples.

\section{REFERENCES}

ABOLNIK, C., HORNER, R.F., MAHARAJ, R. \& VILJOEN, G.J. 2004. Characterization of a pigeon paramyxovirus (PPMV-1) isolated from chickens in South Africa. Onderstepoort Journal of Veterinary Research, 70:157-160.

ALEXANDER, D.J., WILSON, G.W.C., THAIN, J.A. \& LISTER, S.A. 1984. Avian paramyxovirus type 1 infections of racing pigeons: 3 Epizootiological considerations. Veterinary Record, 115:213-216.

ALEXANDER, D.J., RUSSELL, P.H., PARSONS, G., ABU ELZEIN, E.M., BALLOUH, A., CERNIK, K., ENGSTROM, B., FEVEREIRO, M., FLEURY, H.J.A., GUITTET, M., KALETA, E.F., KIHM, U., KOSTERS, J., LOMNICZI, B., MEISTER, J., MEULEMANS, G., NEROME, K., PETEK, M., POKOMUNSKI, S., POLTEN, B., PRIP, M., RICHTER, R., SÁGHY, E., SAMBERG, Y., SPANOGHE, L. \& TUMOVA, B. 1985. Antigenic and biological characterization of avian paramyxovirus type 1 isolates from pigeons-an international collaborative study. Avian Pathology, 14:365-376.

ALEXANDER, D.J. \& PARSONS, G. 1986. Pathogenicity for chickens of avian paramyxovirus type 1 isolates obtained from pigeons in Great Britain during 1983-85. Avian Pathology, 15:487-493.

ALDOUS, E.W., FULLER, C.M., MYNN, J.K. \& ALEXANDER, D.J. 2004. A molecular epidemiological investigation of isolates of the variant avian paramyxovirus type 1 virus (PPMV-1) responsible for the 1978 to present panzootic in pigeons. Avian Pathology, 33:258-269.

BIANCIFIORI, F. \& FIORONI, A. 1983. An occurrence of Newcastle disease in pigeons: virological and serological studies on the isolates. Comparative Immunology, Microbiology and Infectious Diseases, 6:247-252.

COLLINS, M.S., STRONG, I. \& ALEXANDER, D.J. 1994. Evaluation of the molecular basis of pathogenicity of the variant Newcastle disease virus termed "pigeon PMV-1 viruses". Archives of Virology, 134: 403-411.

HALL, T.A. 1999. BioEdit: a user-friendly biological sequence alignment editor and analysis program for Windows 95/98/ NT. Nucleic Acids Symposium Series 41:95-98.

Johnston KM, Key DW. 1992. Paramyxovirus-1 in feral pigeons (Columba livia) in Ontario. Canadian Veterinary Journal, 28: 601-603.

KALETA, E.F. 1992a. Unique features of the pigeon PMV-1 infection, in Workshop on Avian Paramyxoviruses, edited by E.F. Kaleta \& U. Heffels-Redmann. Rauischholzhausen, Germany. 27-29:250-261.
KALETA, E.F. 1992b. Paramyxoviruses in free-living and captive birds- a brief account, in Workshop on Avian Paramyxoviruses, edited by E.F. Kaleta \& U. Heffels-Redmann. Rauischholzhausen, Germany. 27-29:262-271.

KING, D.J. 1996. Avian paramyxovirus type 1 from pigeons: isolate characterization and pathogenicity after chicken or embryo passage of selected isolates. Avian Diseases, 40:707714.

KOMMERS, G.D., KING, D.J., SEAL, B.S. \& BROWN, C.C. 2001. Virulence of pigeon-origin Newcastle disease virus isolates for domestic chickens. Avian Diseases, 45:906921.

KUMAR, S., TAMURA, K. \& NEI, M. 2004. MEGA3: Integrated software for Molecular Evolutionary Genetics Analysis and sequence alignment. Briefings in Bioinformatics, 5:150-163.

LANA, D.P., SNYDER, D.B., KINK, D.J. \& MARQUART, W.W. 1988. Characterization of a battery of monoclonal antibodies for differentiation of Newcastle disease and pigeon paramyxovirus-1 strain. Avian Diseases, 32:273-281.

LEMAHIEU, P., DE VRIESE, L. \& BIJNENS, B.. 1985. Feather abnormalities associated with paramyxovirus 1 variant in pigeons and chickens. Veterinary Record, 116:591.

LISTER, S.A., ALEXANDER, D.J. \& HOGG, R.A. 1986. Evidence for the presence of avian paramyxovirus type 1 in feral pigeons in England and Wales. Veterinary Record, 118:476479.

LOMNICZI, B., WEHMAN, E., HERCZEG, J., BALLAGIPORDANY, A., KALETA, E.F., WERNER, O., MEULEMANS, G., JORGENSEN, P.H., MANTÉ, A.P., GIELKENS, A.L.J., CAPUA, I. \& DAMOSER, J. 1998. Newcastle disease outbreaks in recent years in Western Europe were caused by old (VI) and a novel genotype (VII). Archives of Virology, 143: 49-64.

MASE, M., IMAI, K., SANADA, Y., SANADA, N., YUASA, N., IMADA, T., TSUKAMOTO, K. \& YAMAGUCHI, S. 2002. Phylogenetic analysis of Newcastle disease virus genotypes isolated in Japan. Journal of Clinical Microbiology, 40(10): 3826-3830.

MEULEMANS, G., VAN DEN BERG, T.P., DECAESSTECKER, M. \& BOSCHMANNS, M. 2002. Evolution of pigeon Newcastle disease virus strains. Avian Patholology, 31:515-519.

MONNE, I., BEATO, M.S., CAPUA, I. \& MANDOLA, M.L. 2006. Pigeon paramyxovirus isolated from a robin in Italy. Veterinary Record, 1:158-384.

PIENAAR, A.C.E. \& CILLIERS, J.A. 1987. The isolation of a paramyxovirus from pigeons in South Africa. Onderstepoort Journal of Veterinary Research, 54:653-654.

TERREGINO, C., CATTOLI, G., GROSSELE, B., BERTOLI, E., TISATO, E. \& CAPUA, I. 2003. Characterization of Newcastle disease virus isolates obtained from Eurasian collared doves (Streptopelia decaocto) in Italy. Avian Pathology, 32:63-68.

UJVÁRI, D., WEHMAN, E., KALETA, E.F., WERNER, O., SAVIĆ, V., NAGY, E., CZIFRA, G. \& LOMNICZI, B. 2003. Phylogenetic analysis reveals extensive evolution of avian paramyxovirus type 1 strains of pigeons (Columba livia) and suggests multiple species transmission. Virus Research, 96: 63-73.

WERNER, O., RÖMER-OBERDÖRFER, A., KÖLLNER, B., MANVELL, R.J. \& ALEXANDER, D.J. 1999. Characterization of avian paramyxovirus type 1 strains isolated in Germany during 1992 to 1996. Avian Pathology, 28:79-88.

WILSON, G.W. 1986. Newcastle disease and paramyxovirus 1 of pigeons in the European Community. World Poultry Science Journal, 42:143-153. 